\title{
Deconvolution of boundary layer depth and aerosol constraints on cloud water path in subtropical stratocumulus decks
}

\author{
Anna Possner ${ }^{1}$, Ryan Eastman ${ }^{2}$, Frida Bender ${ }^{3}$, and Franziska Glassmeier ${ }^{4}$ \\ ${ }^{1}$ Institute for Atmospheric and Environmental Sciences, Goethe University, Frankfurt am Main, Germany \\ ${ }^{2}$ Department of Atmospheric Sciences, University of Washington, Seattle, WA, USA \\ ${ }^{3}$ Department of Meteorology and Bolin Centre for Climate Research, Stockholm University, Stockholm, Sweden \\ ${ }^{4}$ Department of Environmental Sciences, Wageningen University, Wageningen, the Netherlands
}

Correspondence: Anna Possner (apossner@iau.uni-frankfurt.de)

Received: 20 September 2019 - Discussion started: 17 October 2019

Revised: 10 February 2020 - Accepted: 25 February 2020 - Published: 26 March 2020

\begin{abstract}
The liquid water path (LWP) adjustment due to aerosol-cloud interactions in marine stratocumulus remains a considerable source of uncertainty for climate sensitivity estimates. An unequivocal attribution of LWP adjustments to changes in aerosol concentration from climatology remains difficult due to the considerable covariance between meteorological conditions alongside changes in aerosol concentrations. We utilise the susceptibility framework to quantify the potential change in LWP adjustment with boundary layer (BL) depth in subtropical marine stratocumulus. We show that the LWP susceptibility, i.e. the relative change in LWP scaled by the relative change in cloud droplet number concentration, in marine BLs triples in magnitude from -0.1 to -0.31 as the BL deepens from 300 to $1200 \mathrm{~m}$ and deeper.

We further find deep BLs to be underrepresented in pollution tracks, process modelling, and in situ studies of aerosolcloud interactions in marine stratocumulus. Susceptibility estimates based on these approaches are skewed towards shallow BLs of moderate LWP susceptibility. Therefore, extrapolating LWP susceptibility estimates from shallow BLs to the entire cloud climatology may underestimate the true LWP adjustment within subtropical stratocumulus and thus overestimate the effective aerosol radiative forcing in this region.

Meanwhile, LWP susceptibility estimates in deep BLs remain poorly constrained. While susceptibility estimates in shallow BLs are found to be consistent with process modelling studies, they overestimate pollution track estimates.
\end{abstract}

\section{Introduction}

The aerosol radiative forcing due to changes in cloud reflectivity of low-level marine clouds remains one of the largest sources of physical uncertainty in climate sensitivity estimates. Estimates of total aerosol radiative forcing from the Fifth Assessment Report (AR5) issued by the Intergovernmental Panel on Climate Change (IPCC) range from -0.1 to $-1.9 \mathrm{~W} \mathrm{~m}^{-2}$ (Boucher et al., 2013; Zelinka et al., 2014). Based on these estimates, increased cloud reflectivity due to anthropogenic aerosol may have posed a substantial offset to the greenhouse gas forcing.

However, this cooling term is likely to reduce in coming years as anthropogenic emissions of aerosols decline (Smith and Bond, 2014). Yet, the quantification of aerosol-induced changes in cloud scene albedo remains important for reducing the uncertainty in overall forcing. Subtropical marine stratocumulus are of particular relevance; the stratocumulus decks in the subtropics contribute strongly to the cooling of the planet by reflecting $\sim 40 \%$ of incoming solar radiation on average, in a region of high solar intensity (Bender et al., 2011).

In particular, cloud adjustments to changes in aerosol concentration remain highly uncertain (Bellouin et al., 2019). As defined in IPCC AR5 (Boucher et al., 2013), adjustments quantify the net response of cloud-radiative properties to external forcing agents such as anthropogenic aerosols. Through microphysical or thermodynamic adjustments, such as decreased precipitation rates (Albrecht, 1989), increased mixing rates at cloud top (Ackerman et al., 2004), or 
the sedimentation-entrainment feedback (Bretherton et al., 2007), the thermodynamics of the cloud is impacted and the liquid water path (LWP) may be altered. Adjustments in cloud fraction $(\mathrm{CF})$ by changes in aerosol concentration may also increase the overall albedo of the cloud scene (Gryspeerdt et al., 2016; Andersen et al., 2017; Possner et al., 2018). However, these effects cannot be addressed within the framework of this study due to the insufficient accuracy in CF retrievals under polluted conditions (e.g. Twohy et al., 2009). It is therefore mentioned here for completeness but will not be discussed further.

In order to constrain the uncertainty range reflected within the wide range of AR5 forcing estimates, numerous studies have since quantified the individual contributions of the Twomey effect (Twomey, 1991) and LWP adjustments in global-scale long-term satellite records (Sekiguchi et al., 2003; Quaas et al., 2008; Lebsock et al., 2008; Bellouin et al., 2013; Bender et al., 2016; Gryspeerdt et al., 2017, 2019; McCoy et al., 2017; Rosenfeld et al., 2019), pollution track data sets (Ackerman et al., 2000; Christensen and Stephens, 2011; Christensen et al., 2014; Chen et al., 2015; Malavelle et al., 2017; Toll et al., 2017, 2019; Bender et al., 2019), and large-eddy simulations (LES) or cloud-resolving simulations in combination with field observations (see Fig. 1 for references). Satellite-based estimates of large data sets provide long-term near-global constraints for the Twomey effect and the LWP adjustment. However, they are prone to numerous sources of uncertainties. These include, but are not limited to, uncertainties in $N_{\mathrm{d}}$ changes for a given change in aerosol metric, the distortion of the true sensitivity due to relatively coarse retrieval scales (McComiskey and Feingold, 2012), and the covariability between meteorological factors and aerosol indices. Average forcing estimates for the Twomey effect alone range between -0.2 and $-1.0 \mathrm{~W} \mathrm{~m}^{-2}$ (Quaas et al., 2008; Lebsock et al., 2008; Bellouin et al., 2013; McCoy et al., 2017). The LWP adjustment may induce a partially compensating positive forcing to the Twomey effect, due to a decrease in cloud field LWP (Gryspeerdt et al., 2019). Meanwhile, the LWP adjustment inside the convective cores of low clouds may be positive (Rosenfeld et al., 2019), which would locally amplify the aerosol-cloud forcing due to the Twomey effect.

In the case of pollution tracks, the issue of covariability between confounding factors is avoided, and a clear detection and attribution of the cloud response to the aerosol perturbation itself, or at least to the corresponding change in $N_{\mathrm{d}}$, is possible. Each individual track is associated with a spatially confined cloud response due to aerosol perturbations by ship or volcano plumes for a given set of meteorological conditions. However, these tracks are rare. It is estimated that merely $0.002 \%$ of all ocean-going ships generate a ship track (Campmany et al., 2009). Though a recent estimate suggests that this number might underestimate the true ship track frequency (Yuan et al., 2019). Furthermore, they are only found within a narrow window of meteorological condi- tions (Durkee et al., 2000). Therefore, while these estimates are prone to fewer uncertainties in detection and attribution of aerosol forcing, the representativeness of such estimates remains unclear.

The same holds true for estimates based on LES, cloudresolving model studies, and field observations. At this resolution, insights into the interplay between microphysical, radiative, and thermodynamic processes can be obtained. Yet, the estimates are representative of the conditions sampled and may not be valid generally or at larger spatial scales. The LES community recently started to address these limitations, e.g. through extensive LES ensembles (Glassmeier et al., 2019). Here we would like to draw attention to the fact that previous analyses of LES, cloud-resolving models, and field campaigns have predominantly focused on shallow boundary layers. Figure 1 shows that most field campaigns and high-resolution modelling studies quantifying aerosolcloud-radiation interactions have been conducted in BLs below $1 \mathrm{~km}$ in depth.

Figure 1 shows the global distribution of stratocumulus regimes across BL depth, which was characterised by Muhlbauer et al. (2014) in terms of cloud-top height (Fig. 10 in Muhlbauer et al., 2014). The probability density function (PDF) by Muhlbauer et al. (2014) is representative of all low clouds over the oceans (see original paper for further methodology). We find the global PDF to be comparable to the distribution of stratocumulus against BL depth in the subtropics alone (Fig. S1 in the Supplement). The PDF for disorganised clouds in Fig. 10 of Muhlbauer et al. (2014) was omitted here. These scenes were governed by broken cloud decks of low $\mathrm{CF}(\overline{\mathrm{CF}}=40 \%)$, resembling shallow cumulus rather than stratocumulus.

The LWP adjustment within shallow cumulus seems to be governed by lateral entrainment effects and moisture gradients (e.g. Jiang et al., 2006; Seifert et al., 2015). This is in stark contrast to stratocumulus cloud decks $(\mathrm{CF}>80 \%)$ where the LWP adjustment is predominantly governed by vertical gradients in moisture, stability, and aerosol. Thus, the LWP adjustment in shallow cumulus may differ from adjustments in stratocumulus, which is the focus of this study. The distinction between detraining shallow cumulus under strong inversions and precipitating stratocumulus becomes semantic in the case of cloud scenes associated with high cloud fraction. For this reason, results of the Atlantic Trade Wind Experiment (ATEX) are included in Fig. 1.

In the subtropics merely $30 \%$ of stratocumulus reside at the predominant depth range sampled in the field and studied within most high-resolution simulations. Results from merely three campaigns and few modelling studies are discussed within the literature that reside within a height range deeper than $1 \mathrm{~km}$ where over $70 \%$ of marine stratocumulus are found. The campaigns containing measurements of deep stratocumulus cloud decks are ATEX, EPIC (East Pacific Investigation of Climate), and VOCALSREx (VAMOS - Variability of the American Monsoons 


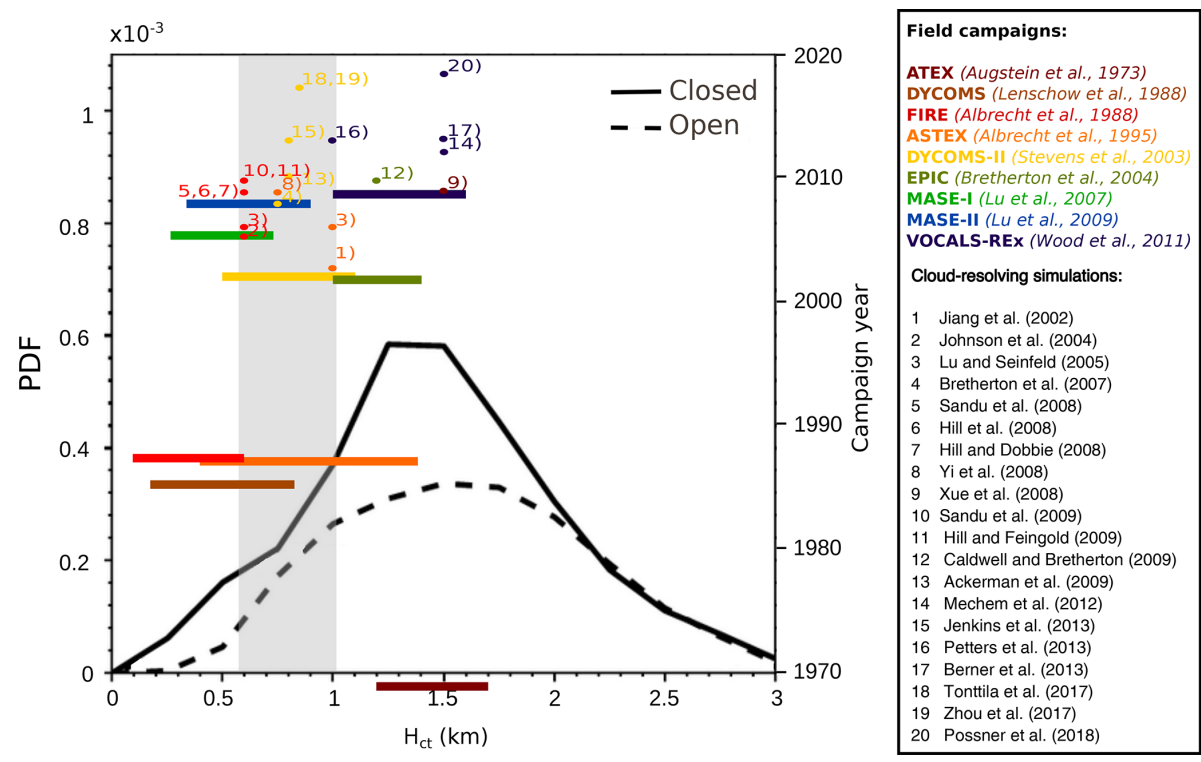

Figure 1. Probability density function (PDF) for closed, open-cell, and disorganised stratocumulus layers against cloud-top height. This figure is adapted from Fig. 10 in Muhlbauer et al. (2014). Coloured bars denote the range of cloud-top heights sampled during each campaign listed in the legend. LES and cloud-resolving studies investigating aerosol-cloud-radiation interactions are colour-coded by the campaigns they are based on (with the exception of model study 8, which is based on an idealised profile). Grey shading denotes narrow BL-depth interval within which $75 \%$ of all modelling studies reside. Future analyses of past campaigns summarised in Zuidema et al. (2016) will likely increase the data points sampled in deeper BLs. References: Jiang et al. (2002), Johnson et al. (2004), Lu and Seinfeld (2005), Bretherton et al. (2007), Sandu et al. (2008), Hill et al. (2008), Hill and Dobbie (2008), Yi et al. (2008), Xue et al. (2008), Caldwell and Bretherton (2009), Ackerman et al. (2009), Sandu et al. (2009), Hill and Feingold (2009), Mechem et al. (2012), Jenkins et al. (2013), Petters et al. (2013), Berner et al. (2013), Tonttila et al. (2017), Zhou et al. (2017), Possner et al. (2018), Augstein et al. (1973), Lenschow et al. (1988), Albrecht et al. (1988, 1995), Stevens et al. (2003), Bretherton et al. (2004), Lu et al. (2007, 2009), and Wood et al. (2011).

- Ocean-Cloud-Atmosphere-Land Study Regional Experiment). Merely $25 \%$ (Fig. 1) of all high-resolution modelling studies investigating the influence of aerosol concentrations on cloud properties in marine stratocumulus decks (i.e. Xue et al., 2008; Caldwell and Bretherton, 2009; Mechem et al., 2012; Berner et al., 2013; Possner et al., 2018) are based on deep BL field campaigns.

The lack of process studies in deep boundary layers, despite their prominence, motivates us to explore the dependence of cloud adjustments on BL depth. This is further supported by recent findings that show an explicit dependence of the LWP adjustment on BL depth in pollution tracks (Toll et al., 2019). Here, we focus on regions dominated by marine stratocumulus, and we explore these relationships within 10year records in the subtropics. The data set is described in Sect. 2. The change of mean cloud properties with BL depth is presented in Sect. 3, while the impact of BL-depth covariance with LWP, and $N_{\mathrm{d}}$ on the LWP adjustment estimate, is presented in Sect. 4.

\section{Data description}

The relationship between LWP and $N_{\mathrm{d}}$ at different BL depths is analysed in the semi-permanent stratocumulus regions of the subtropics (Fig. 2). The analysis is based on a 10-year climatology of daily in-cloud radiation retrievals between 2007 and 2016, at a spatial resolution of $1^{\circ} \times 1^{\circ}$. Daytime in-cloud retrievals for LWP, $N_{\mathrm{d}}$, and effective radius $\left(R_{\text {eff }}\right)$ are obtained from the level 3 Moderate Resolution Imaging Spectroradiometer (MODIS) collection 6 product (King et al., 2003; Platnick et al., 2017). As in previous collections, independent retrievals of cloud optical depth and $R_{\text {eff }}$ are obtained using the visible and near-infrared radiances at 2.1 and $0.86 \mu \mathrm{m}$ (Platnick et al., 2003).

The $R_{\text {eff }}$ retrieval is further used to distinguish between precipitating $\left(R_{\text {eff }} \geq 15 \mu \mathrm{m}\right)$ and non-precipitating $\left(R_{\text {eff }}<\right.$ $15 \mu \mathrm{m})$ cloud scenes. For the year 2007, an independent retrieval of precipitation probability (Eastman et al., 2019) was available (Fig. S2). During this year, the $R_{\text {eff }}$ criterion splits the data set into regimes where the precipitation probability remains below $50 \%$ (equivalent to non-precipitating clouds) and above $50 \%$ (equivalent to precipitating clouds).

$N_{\mathrm{d}}$ is estimated based on the relationship established by Boers et al. (2006) and Bennartz (2007) for marine boundary layer clouds:

$$
N_{\mathrm{d}}=\sqrt{2} \frac{3}{4 k \pi \rho_{\mathrm{W}}} \Gamma_{\text {eff }}^{\frac{1}{2}} \frac{\mathrm{LWP}^{\frac{1}{2}}}{R_{\mathrm{eff} \mid \text { top }}^{3}},
$$



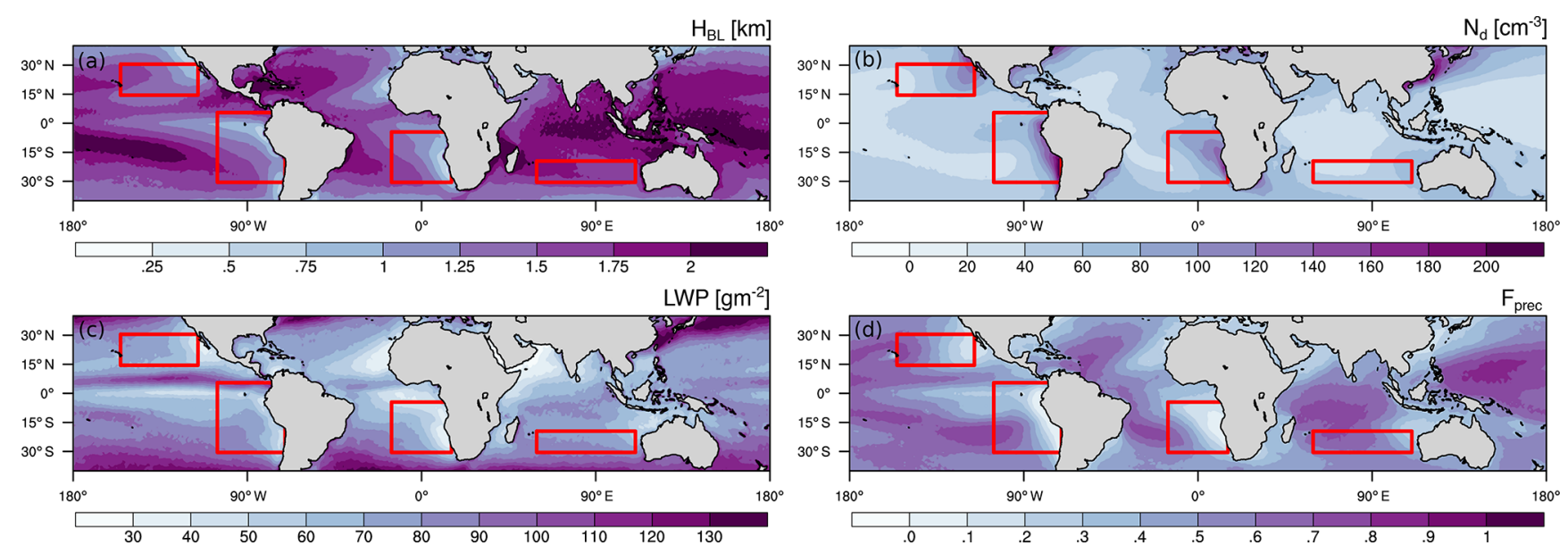

Figure 2. (a) Boundary layer height $\left(H_{\mathrm{BL}}\right)$, (b) cloud droplet number concentration $\left(N_{\mathrm{d}}\right)$, (c) liquid water path (LWP), and (d) low-cloud precipitation probability $\left(F_{\text {prec }}\right)$ are shown. Regions of subtropical stratocumulus decks are marked in red and were defined in Eastman and Wood (2016) based on surface observations of Hahn and Warren (2007).

where $\rho_{\mathrm{w}}$ denotes the density of water, $\Gamma_{\mathrm{eff}}=f_{\mathrm{ad}} \Gamma_{\mathrm{ad}}$ is the effective rate of increase in adiabatic liquid water content with increasing height, and $R_{\text {eff } \mid \text { top denotes the effective ra- }}$ dius at cloud top. All assumptions regarding the degree of adiabaticity and the proportionality constant $k$ between the true and effective $N_{\mathrm{d}}$ are the same as in Eastman and Wood (2016).

The retrievals are restricted to sensor viewing angles between 0 and $65^{\circ}$ (Grosvenor and Wood, 2014), which does not pose a strong constraint in the subtropics. The data are further limited to regions with high CFs exceeding $80 \%$. This restriction permits the best possible accuracy in $N_{\mathrm{d}}$ retrievals, which assumes plane-parallel clouds and restricts the analysis to large-scale stratocumulus cloud decks only, which have the largest radiative impact. All cloud properties are in-cloud mean values only, which are not weighted by areal $\mathrm{CF}$ within each $1^{\circ} \times 1^{\circ}$ grid box.

The retrieval of $\mathrm{BL}$ height $\left(H_{\mathrm{BL}}\right)$ used in this study was first presented in Eastman and Wood (2016) and analysed in Eastman et al. (2017). The retrieval is based on a combination of MODIS and Cloud-Aerosol Lidar and Infrared Pathfinder Satellite Observation (CALIPSO) cloud retrievals (Vaughan et al., 2004). The Clouds and the Earth's Radiant Energy System (CERES) Single Scanner Footprint One Degree (SSF1deg) retrievals of all-sky $\left(A_{\text {toa }}\right)$ and clearsky albedo $\left(A_{\mathrm{clr}}\right)$ based on the top-of-atmosphere shortwave fluxes (Kato et al., 2013) were used to estimate $A_{\text {cld }}$ from

$A_{\text {toa }}=\mathrm{CF} \cdot A_{\text {cld }}+(1-\mathrm{CF}) \cdot A_{\text {clr }}$.

It should be noted that the above equation can only provide an estimate of the cloud albedo. This definition, due to the separation of clear and cloudy skies, is highly sensitive to the definition of CF. CF retrievals are afflicted with uncertainty, due to swelling of aerosols in the high-relative-humidity environment near cloud edges (Twohy et al., 2009); rather than a dichotomy, clear and cloudy skies represent a continuum of albedo values (Charlson et al., 2007). Yet, Eq. (2) has been shown to provide a useful estimate of cloud albedo in the subtropical stratocumulus regions we focus on here.

Further environmental factors considered in this study, such as the lower tropospheric stability (LTS) and the free troposphere $(\mathrm{FT})$ relative humidity $\left(\mathrm{RH}_{\mathrm{FT}}\right)$, are obtained from the Modern-Era Retrospective Analysis for Research and Applications Version 2 (MERRA-2) reanalysis (Rienecker et al., 2011; Molod et al., 2015). The LTS is defined as the change in potential temperature between $700 \mathrm{hPa}$ and the surface. Conditions are considered non-stable if the change in potential temperature between these two pressure levels remains below $15 \mathrm{~K}$. $\mathrm{RH}_{\mathrm{FT}}$ is diagnosed as the mean $\mathrm{RH}$ between the inversion and $700 \mathrm{hPa}$. Environmental conditions are considered to be dry if $\mathrm{RH}_{\mathrm{FT}}$ falls below $50 \%$ and moist otherwise.

\section{Covariance between cloud properties and boundary layer depth}

Here, we analyse the change in cloud properties of subtropical stratocumulus as a function of $H_{\mathrm{BL}}$. Each cloud property is binned into $100 \mathrm{~m} H_{\mathrm{BL}}$ intervals within which the 10-year mean and standard deviation are computed. The resulting relationships, which include data from all four predominant stratocumulus cloud decks, are shown in Fig. 3. All cloud properties change significantly (at the $95 \%$ level) with $H_{\mathrm{BL}}$. The largest relative changes are observed for LWP (Fig. 3b) and $N_{\mathrm{d}}$ (Fig. 3e), while merely moderate and small changes are observed in $R_{\text {eff }}$ (Fig. 3d) and $A_{\text {cld }}$ (Fig. 3a), respectively.

The adiabatic LWP $\left(\mathrm{LWP}_{\mathrm{ad}}\right)$ scales with cloud depth $\left(H_{\mathrm{c}}\right)$ as $\mathrm{LWP}_{\mathrm{ad}} \propto H_{\mathrm{c}}^{2}$, where $H_{\mathrm{c}}=H_{\mathrm{BL}}-H_{\mathrm{b}}$ and $H_{\mathrm{b}}$ denotes cloud base. Based on this relationship, we regress lnLWP 

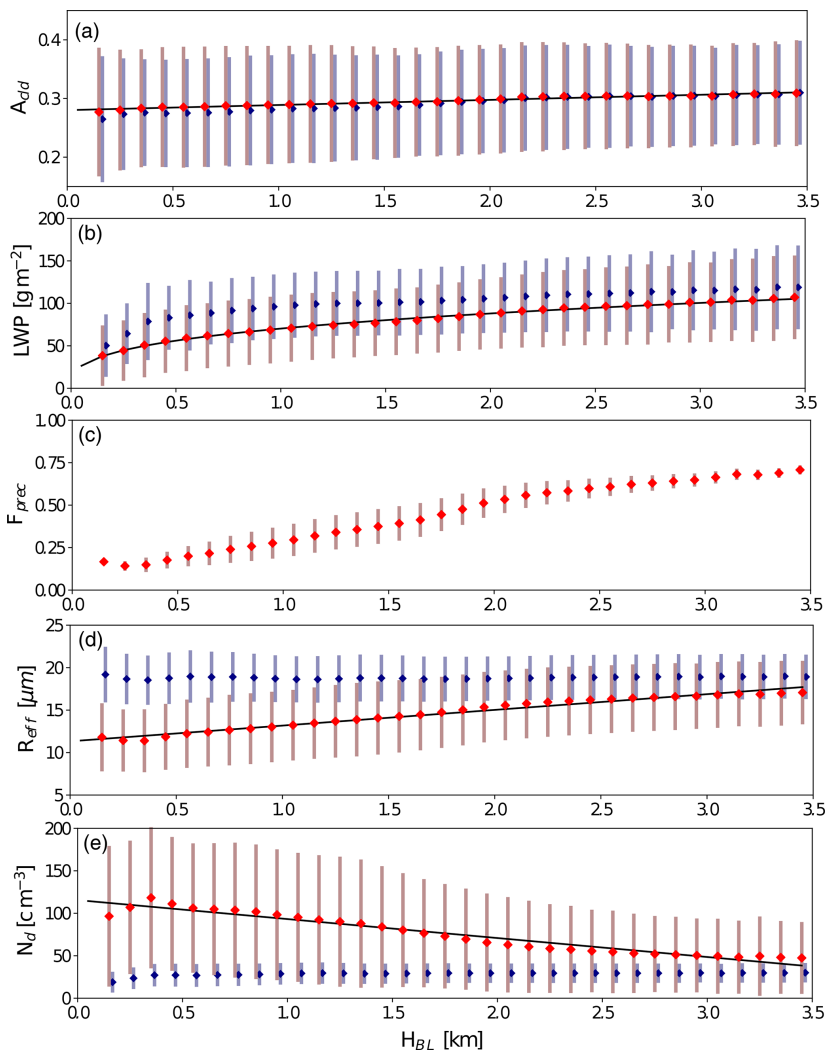

Figure 3. Scaling of (a) $A_{\text {cld }}$, (b) LWP, (c) $F_{\text {prec }}$, (d) $R_{\text {eff }}$, and (e) $N_{\mathrm{d}}$ against $H_{\mathrm{BL}}$. Mean and standard deviation of the 10-year subtropical stratocumulus climatology (see Fig. 2) are shown in red within each height bin (100 m intervals). Fits across the climatology are superimposed in black (see Table 1 for details on fitting parameters). The climatology of precipitating clouds is shown in blue. For completeness, the climatology for non-precipitating clouds is shown in Fig. S3.

against $\ln H_{\mathrm{BL}}$ to identify the exponent of the LWP- $H_{\mathrm{BL}}$ relationship (Fig. 3b). Meanwhile, a simple linear regression is obtained for all other cloud climatologies (Fig. 3a, d, e). To understand the relative sensitivity amongst cloud properties to changes in $H_{\mathrm{BL}}$, the slopes obtained by linear regression in the physical, as opposed to logarithmic space, are scaled by the climatological mean (Table 1).

As expected, larger LWPs are associated with deeper BLs (Fig. 3b). In particular we find LWP to scale as LWP $\propto H_{\mathrm{BL}}^{0.33}$ (Table 1). Therefore, LWP scales considerably weaker with $H_{\mathrm{BL}}$ than $H_{\mathrm{c}}$. Combining these two relationships, it follows that in adiabatic clouds $H_{\mathrm{c}} \propto H_{\mathrm{BL}}^{0.17}$. That is, $H_{\mathrm{c}}$ increases on average by merely $2 \mathrm{~m}$ for every $100 \mathrm{~m}$ increase in $H_{\mathrm{BL}}$. Thus, $H_{\mathrm{c}}$ seems largely independent of $H_{\mathrm{BL}}$ variations.

Adiabaticity is known to change with cloud depth in marine stratocumulus (Merk et al., 2016; Braun et al., 2018). Furthermore, we find that clouds in deep BLs are more likely to precipitate than clouds in shallow BLs (Fig. 3c). Consequently, one might expect cloud adiabaticity to change as a function of $H_{\mathrm{BL}}$ due to the change in likelihood of precipitation $\left(F_{\text {prec }}\right)$. However, we find that the LWP- $H_{\mathrm{BL}}$ relationship is hardly impacted by precipitation (Table 1: columns 6 and 7). It also seems unlikely that the functional relationship between adiabaticity and $H_{\mathrm{c}}$ would be sufficient to reduce the quadratic exponent of the LWP $-H_{\mathrm{c}}$ relationship to that of the sub-linear exponent in the LWP- $H_{\mathrm{BL}}$ relationship. It therefore follows that LWP scales very differently and seemingly independently with $H_{\mathrm{BL}}$ and $H_{\mathrm{c}}$ in marine subtropical stratocumulus.

Thermodynamic adjustments in LWP and $H_{\mathrm{c}}$ occur rapidly (hourly timescale), while adjustments in BL depth and thus LWP occur on longer timescales (multi-day timescale). $H_{\mathrm{c}}$ is predominantly constrained by the vertical displacement of $H_{\mathrm{b}}$, as has been quantified by LWP budgets (Wood, 2007; van der Dussen et al., 2014; Ghonima et al., 2015; Hoffmann et al., 2020). $H_{\mathrm{b}}$ in turn is governed by the Clausius-Clapeyron relation in response to variability in BL humidity and temperature. Meanwhile, the multi-day evolution of $H_{\mathrm{BL}}$ and thus LWP characterises their evolution as a function of external drivers such as gradients in sea surface temperature (SST), FT conditions, and large-scale advection. This is consistent with the weak relationship between $H_{\mathrm{c}}$ and $H_{\mathrm{BL}}$ inferred here from climatology.

LWP increases more rapidly with $H_{\mathrm{BL}}$ under dry FT and non-stable lower tropospheric conditions (Table 1 columns 2-4). This behaviour is consistent with cloud-scale observations (Eastman and Wood, 2018), simulations (Bretherton et al., 2013), and mixed-layer theory (Dal Gesso et al., 2014). Under low-RHFT conditions, cloud-top cooling and cloud-top-generated mixing are more effective. Therefore, a deeper and moister mixed layer associated with larger LWP can be maintained. Thus, the reinforcement of the cloud through stronger radiative cooling has a larger impact on LWP, than the increased drying through entrainment under low-RHFT conditions. Similarly, the weaker buoyancy jump across the inversion under non-stable lower troposphere conditions likely induces less warming in the sub-cloud layer as the BL deepens, which corresponds to a weaker upward shift of the cloud base.

Meanwhile, deeper BLs are characterised by lower $N_{\mathrm{d}}$ (Fig. 3e). As the BL deepens, $F_{\text {prec }}$ (Fig. 3c), and thus the $N_{\mathrm{d}}$ sink through collision-coalescence processes, increases. Yet, $N_{\mathrm{d}}$ primarily decreases with $H_{\mathrm{BL}}$ in non-precipitating BLs (Fig. S3). This suggests that precipitation scavenging is not the only constraint on $N_{\mathrm{d}}$. In the absence of precipitation, we attribute the negative correlation between $N_{\mathrm{d}}$ and $H_{\mathrm{BL}}$ to (i) the climatological deepening of the BL away from the cold upwelling zones near the coasts (Fig. 2a) and (ii) the increasing distance to continental sources of anthropogenic pollution, which manifest in a pronounced negative gradient in $N_{\mathrm{d}}$ (Fig. 2b). This is also explicitly illustrated in Fig. S4.

The negative correlation vanishes in a deregionalised and deseasonalised version of this data set (Fig. S5). Following Bender et al. (2016), we remove geographical and seasonal 
trends. In doing so, the significant negative correlation between $N_{\mathrm{d}}$ and $H_{\mathrm{BL}}$ in non-precipitating clouds disappears. This further confirms that the observed negative correlation between $N_{\mathrm{d}}$ and $H_{\mathrm{BL}}$ in non-precipitating clouds is intrinsic to the data, but it is not a manifestation of a given physical process.

The observed negative correlation disappears in the presence of precipitation (Fig. 3e and Table 1). Our two process hypotheses governing the negative correlation between $N_{\mathrm{d}}$ and $H_{\mathrm{BL}}$ are not impacted directly by precipitation. Yet the negative correlation vanishes. This also holds true for the deseasonalised and deregionalised $N_{\mathrm{d}}$ climatology (Fig. S5). It follows that precipitation is the predominant constraint on climatological $N_{\mathrm{d}}$ in subtropical marine stratocumulus at this scale. In addition $F_{\text {prec }}$ changes with $H_{\mathrm{BL}}$. Thus, a significant negative slope manifests within the whole $N_{\mathrm{d}}$ climatology $\left(\overline{c_{N_{\mathrm{d}}}}=-0.3\right)$, as the fraction of precipitating to nonprecipitating clouds changes. Therefore, the $N_{\mathrm{d}}$ climatology of all subtropical stratocumulus is constrained to a first-order approximation by precipitation and to a second-order approximation by the proximity to sources of cloud condensation nuclei.

The weakly positive scaling in $R_{\text {eff }}$ against $H_{\mathrm{BL}}$ is consistent with the relationships between LWP, $N_{\mathrm{d}}$, and $H_{\mathrm{BL}}$. The decrease in $N_{\mathrm{d}}$ with $H_{\mathrm{BL}}$ is insufficient to offset the increase in LWP. The combined increase in LWP and $R_{\text {eff }}$ with BL deepening results in a significant but inconsequential increase in $A_{\text {cld }}$ with $H_{\mathrm{BL}}$ (Table 1). Stratocumulus with cloud tops above $1 \mathrm{~km}$ are associated with larger LWP, lower $N_{\mathrm{d}}$, larger $R_{\text {eff }}$, and an elevated $A_{\text {cld }}$ of 0.01 as compared to stratocumulus with cloud tops below $1 \mathrm{~km}$.

\section{Liquid water path adjustment}

The climatological fields of LWP and $N_{\mathrm{d}}$ display a significant correlation and anticorrelation with $H_{\mathrm{BL}}$. The largest climatological values of LWP are found in deep BLs with low $N_{\mathrm{d}}$ (Fig. 4a). The increase in LWP with $H_{\mathrm{BL}}$ is consistent with Fig. 3b. The displayed sensitivity of LWP to $N_{\mathrm{d}}$ is potentially attributable to a multitude of competing factors, and not all are representative of cloud adjustments. The decrease in LWP with increased levels of pollution has been noted multiple times in observations, and various process hypotheses have been put forward.

Less polluted clouds could potentially be associated with weaker entrainment drying through the entrainmentsedimentation feedback (Bretherton et al., 2007). Alternatively, increased rates of precipitation in cleaner environments could stabilise the cloud (Wood, 2012), which results in weaker overall cloud-top entrainment of dry subsaturated air (Ackerman et al., 2004). Furthermore, recent results show that the strengthening of convective overturning in the subcloud layer through precipitation can also have a net positive impact on LWP (Goren et al., 2018). All these are ex-
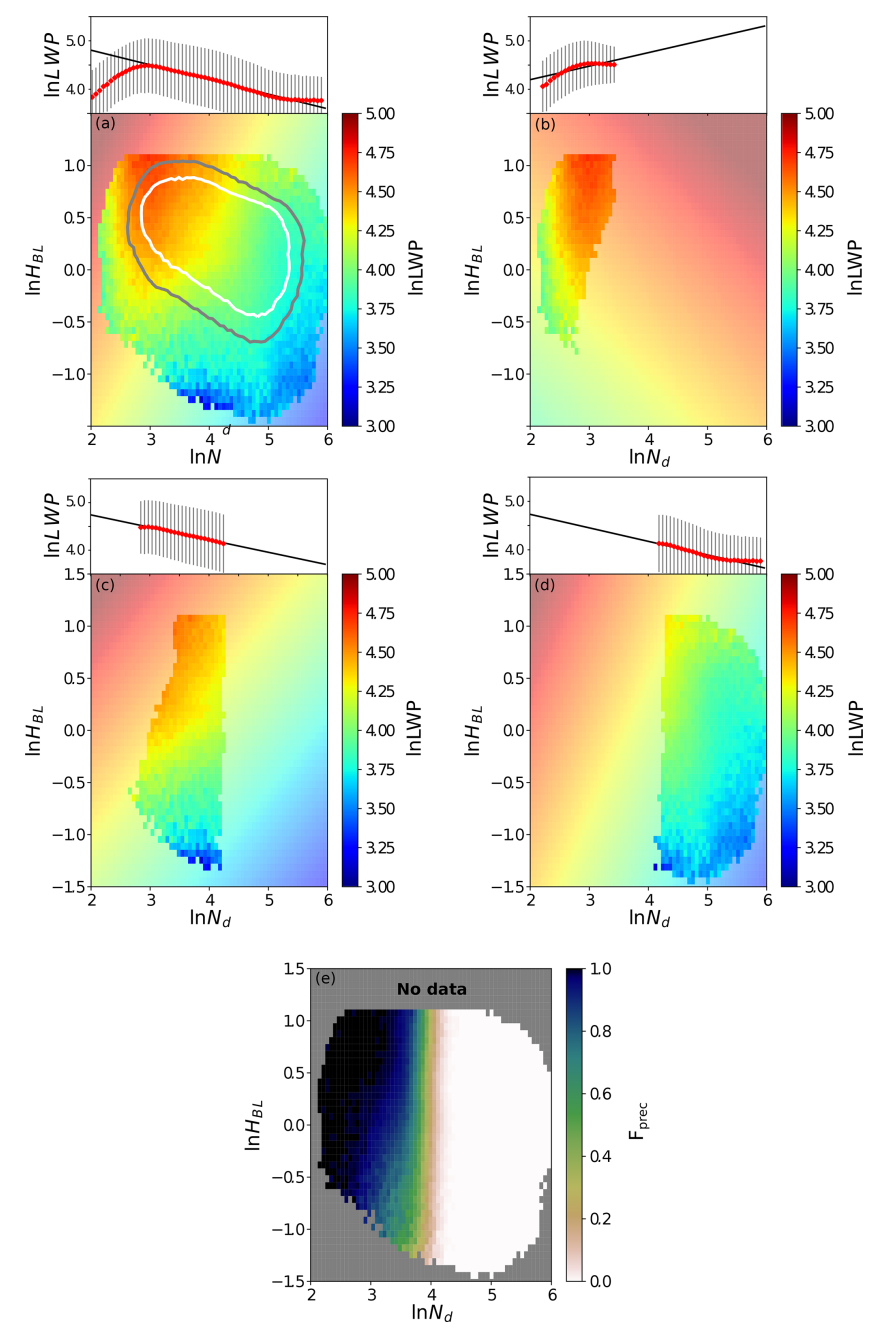

Figure 4. Climatology of $\ln L W P$ against $\ln N_{\mathrm{d}}$ and $\ln H_{\mathrm{BL}}$ for (a) all subtropical stratocumulus (see Fig. 2), (b) fully precipitating stratocumulus, (c) intermittently precipitating stratocumulus, and (d) non-precipitating stratocumulus. Points are classified as fully precipitating (non-precipitating) if the fraction of precipitating cloud scenes shown in (e) exceeds 0.98 (remains below 0.02). All other cloud scenes are classified as intermittently precipitating. At the top of panels (a)-(d), $\ln L W P$ binned in $\ln N_{\mathrm{d}}$ is shown as in Gryspeerdt et al. (2019). A minimum number of 100 points within each $\ln N_{\mathrm{d}}-\ln H_{\mathrm{BL}}$ bin was required to be included in the climatology shown in opaque contours (a-e). The bivariate (simple linear) regression across the two-dimensional (one-dimensional) climatology is shown in transparent contours (as black line) in panels (a)(d). White and grey lines in (a) denote the region of the phase space containing $80 \%$ and $90 \%$ of all data, respectively. The slopes of all fits are summarised in Table 1.

amples of adjustments to the initial cloud microphysical response caused by an increase in droplet number. However, other factors not representative of cloud adjustments, such as the climatological covariance between $H_{\mathrm{BL}}$ and $N_{\mathrm{d}}$ noted in Sect. 3, may impact $s_{\text {lwp }}$ estimates. 
Table 1. This table summarises the regime dependence of each slope. The relationship between cloud properties and $H_{\mathrm{BL}}$ is determined logarithmically ( $\ln \Psi \sim c_{\ln \Psi} \times \ln H_{\mathrm{BL}}$ for $\left.\Psi=\mathrm{LWP}\right)$ or as normalised linear slopes $\left(\overline{c_{\Psi}}=c_{\Psi} / \bar{\Psi}\right.$ where $\Psi \sim c_{\Psi} \times H_{\mathrm{BL}}$ for $\Psi \in\left\{R_{\mathrm{eff}}, N_{\mathrm{d}}, A_{\mathrm{cld}}\right\}$ and $\bar{\Psi}$ denotes the average). Slopes were determined by linear regression if and only if (i) a significant fit was obtained at the $95 \%$ confidence level and (ii) the fit explained at least $80 \%$ of the variance of the climatological relationship shown in Fig. 3. If no such fit is obtained, " $\times$ " is given. The regime dependence of $s_{\text {lwp }}$, which is defined and discussed in Sect. 4, is summarised in the last two rows. Estimates for $s_{\text {lwp }}$ were either obtained by simple linear regression or by a bivariate fit taking the covariability between LWP, $N_{\mathrm{d}}$, and $H_{\mathrm{BL}}$ into account. All slopes are given to the significant digit, which is determined based on the error of the respective fit. Error statistics and sample sizes for each category are provided in Table S1 in the Supplement.

\begin{tabular}{lrr|rr|r|r|r|r}
\hline \multirow{2}{*}{ Quantity } & \multicolumn{2}{c}{ Stability } & \multicolumn{2}{c}{ Above-cloud RH } & \multicolumn{2}{c}{ Cloud-base precipitation } & All \\
\cline { 2 - 8 } & Stable & Non-stable & Dry & Moist & No-rain & Rain & \\
\hline$c_{\text {ln LWP }}$ & 0.4 & 0.6 & 0.5 & 0.2 & 0.3 & 0.3 & 0.42 \\
$\overline{c_{R_{\text {eff }}}}$ & 0.10 & 0.08 & 0.13 & 0.13 & 0.07 & $\times$ & 0.13 \\
$c_{N_{\mathrm{d}}}$ & -0.2 & $\times$ & -0.3 & -0.28 & -0.13 & $\times$ & -0.3 \\
$c_{A_{\text {cld }}}$ & 0.03 & 0.04 & 0.04 & $\times$ & 0.03 & 0.04 & 0.03 \\
\hline & & & & & Fully & Intermittently & \\
\hline$s_{\text {lwp }}$ (bivariate) & -0.29 & -0.18 & -0.29 & -0.15 & -0.28 & 0.14 & -0.23 & -0.28 \\
$s_{\text {lwp }}\left(N_{\mathrm{d}}\right.$ only) & -0.31 & -0.2 & -0.32 & -0.16 & -0.28 & 0.28 & -0.26 & -0.33 \\
\hline
\end{tabular}

Here, we estimate $s_{\text {lwp }}$ by either fitting $\ln L W P$ against $\ln N_{\mathrm{d}}$ as in Gryspeerdt et al. (2019) or by fitting the twodimensional surface of $\ln L W P$ against $\ln H_{\mathrm{BL}}$ and $\ln N_{\mathrm{d}}$. Both fits are simple linear, single-, or bivariate regressions across the phase space containing $80 \%$ of all data (Fig. 4a). Both fitting approaches yield similar negative $s_{1 \mathrm{wp}}$ estimates. Taking the covariance with $H_{\mathrm{BL}}$ into account merely reduces the magnitude of $s_{\text {lwp }}$ from -0.33 , which is consistent with previous global estimates of marine low-level clouds (Gryspeerdt et al., 2019), to -0.28 (Table 1). Therefore, the bivariate fit of the entire climatology is likely subject to the same confounding factors impacting LWP adjustments as in Gryspeerdt et al. (2019). Furthermore, the two predictor variables, $H_{\mathrm{BL}}$ and $N_{\mathrm{d}}$, of the bivariate fit are not independent (Fig. 3e), which may bias the $s_{\text {lwp }}$ estimate.

The entire phase space can be further characterised by $F_{\text {prec }}$ (Fig. 4e): $14 \%$ (Table S1) of the climatological phase space is characterised by precipitating cloud scenes (Fig. 4b), $37 \%$ by intermittently precipitating cloud scenes (Fig. 4c), and $48 \%$ by non-precipitating clouds (Fig. $4 \mathrm{~d}$ ). The analysis shows that $\ln L W P$ increases with $\ln N_{\mathrm{d}}$ in the precipitating fraction of the cloud climatology $\left(s_{1 \mathrm{wp}}=0.14\right)$ and decreases in the intermittently $\left(s_{\mathrm{lwp}}=-0.23\right)$ and non-precipitating climatologies $\left(s_{\mathrm{lwp}}=-0.28\right)$. Thus $s_{1 \mathrm{wp}}$ inferred from the entire climatology is dominated by the LWP $-N_{\mathrm{d}}$ relationship in non-precipitating clouds.

The opposing response in precipitating and nonprecipitating regions is consistent with numerous previous studies (Albrecht, 1989; Ackerman et al., 2004; Bretherton et al., 2007; Wood, 2007; Wang et al., 2012; Suzuki et al., 2013; Gryspeerdt et al., 2019). While the largest fraction of $H_{\mathrm{BL}}-N_{\mathrm{d}}$ phase space is characterised by non-precipitating clouds (Table S2), only a narrow band in close proximity to the coast lines of the Americas and the African con- tinent is characterised by little-to-no precipitation $\left(F_{\text {prec }}<\right.$ 0.1 , Fig. 2d). Most regions are characterised by intermittent rain occurrence $\left(0.2<F_{\text {prec }}<0.8\right)$ and are associated with more moderate susceptibilities of -0.23 or less (Fig. 5). Thus the results of Fig. $4 \mathrm{c}$ are representative of most stratocumulus regions in the subtropics. Overall, few stratocumulus regions are associated with an average positive susceptibility.

Non-precipitating and intermittently precipitating cloud climatologies are not sensitive to the fitting technique applied (Table 1). Yet, $s_{\text {lwp }}$ halved when the covariance of LWP with $H_{\mathrm{BL}}$ is taken into account in consistently precipitating clouds. In order to gain further insight into the potential variance of $s_{\text {lwp }}$ with $H_{\mathrm{BL}}$, we calculated $s_{\mathrm{lwp}}$ within constrained BL-depth ranges for the three precipitation regimes characterised in Fig. 4.

Analyses of ship tracks (Christensen and Stephens, 2011) and Lagrangian studies of cloud evolution (Eastman et al., 2017) have shown that $H_{\mathrm{BL}}$ may increase under more polluted conditions. This, however, is not manifested within the $H_{\mathrm{BL}}-N_{\mathrm{d}}$ climatology (Fig. 3e). Therefore, by constraining $s_{\text {lwp }}$ estimates in this manner, we attempt to remove some of the covariance between LWP, $N_{\mathrm{d}}$, and $H_{\mathrm{BL}}$, which may impact the estimated strength of the LWP adjustment.

$S_{\text {lwp }}$ in precipitating subtropical stratocumulus is considerably larger in BLs below $1.5 \mathrm{~km}$ in depth than in deeper BLs (Fig. 6b). While $s_{\text {lwp }}$ may be as large as 0.48 , which constitutes a tremendous cloud adjustment in shallow BLs, it does not exceed 0.08 in deep BL clouds. It should be noted that the large, negative adjustment of $s_{\text {lwp }}=-1.0$ within the first height bin in Fig. 6b is statistically significant but characterises a very small subsample of the total climatology.

Meanwhile, $s_{\text {lwp }}$ increases in magnitude from -0.1 in BLs below $500 \mathrm{~m}$ in altitude to -0.31 in BLs exceeding $1 \mathrm{~km}$ in depth (Fig. 6d). A weaker height dependence is observed 


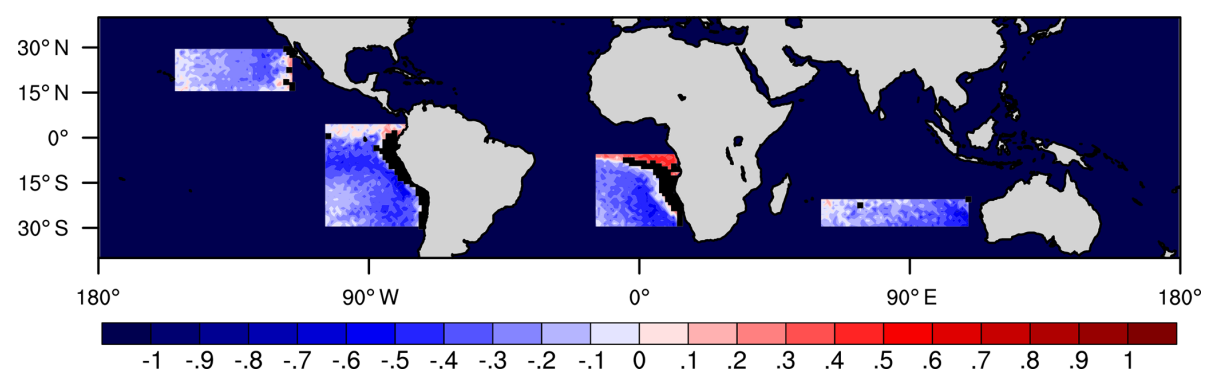

Figure 5. Map of $s_{\text {lwp }}$ which was obtained from bivariate linear regression of daily $\ln L W P, \ln N_{\mathrm{d}}$, and $\ln H_{\mathrm{BL}}$ retrievals at a spatial scale of $1^{\circ} \times 1^{\circ}$. Regions where $s_{1 w p}$ is not statistically significant are masked in black.
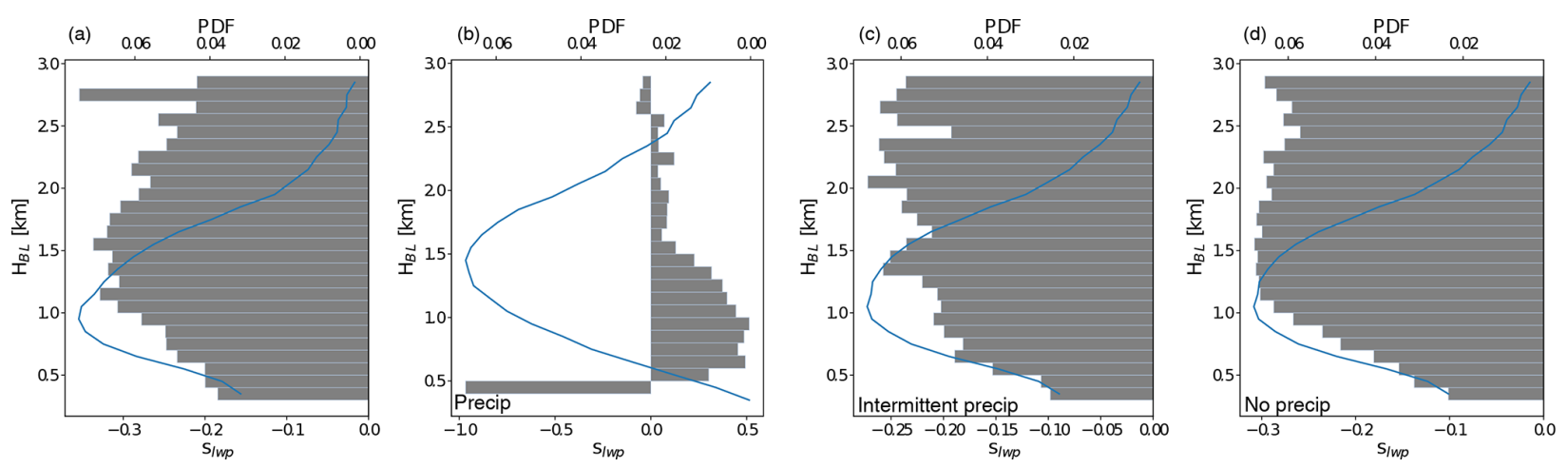

Figure 6. (a) $s_{\text {lwp }}$ determined within $100 \mathrm{~m}$ height intervals for subtropical stratocumulus, (b) precipitating clouds only, (c) intermittently precipitating clouds, and (d) non-precipitating clouds. $S_{\text {lwp }}$ was obtained from bivariate linear regression of the $\ln L W P$ surfaces shown in Fig. 4a-d within each height interval, respectively. Only statistically significant results at the $95 \%$ confidence level are shown. The probability density function (PDF) of the subtropical cloud climatology across the height bins is superimposed.

for intermittently precipitating cloud scenes (Fig. 6c). Both results of Fig. $6 \mathrm{c}$ and $\mathrm{d}$ are consistent with the increase in LWP susceptibility noted within pollution tracks around the globe (Toll et al., 2019). Moreover, the change in $s_{\text {lwp }}$ with $H_{\mathrm{BL}}$ shown in Fig. 6c, which characterises the behaviour in most stratocumulus regions, is within a $1 \sigma$ uncertainty range of $s_{\text {lwp }}$ estimates based on pollution tracks. Within pollution tracks, $s_{\text {lwp }}$ increased in magnitude from less than $-0.01 \pm 0.13$ in shallow BL clouds to $-0.1 \pm 0.13$ for a cloudtop height of $2 \mathrm{~km}$ (Toll et al., 2019).

\section{Discussion and conclusions}

Isolating the LWP adjustment due to changes in $N_{\mathrm{d}}$ from potentially co-varying meteorological factors has remained a significant hindrance to quantifying the radiative forcing of aerosol-cloud interactions. It also is a likely cause of diverging estimates from low-cloud climatology, process-scale models, and pollution track estimates.

Here, we address whether LWP adjustments vary with BL depth and whether climatological susceptibility estimates are impacted by the covariance of cloud properties with $H_{\mathrm{BL}}$. Like previous studies, we find evidence for a positive relationship between LWP and $N_{\mathrm{d}}$ climatologies in precip- itating marine stratocumulus (Albrecht, 1989; Christensen and Stephens, 2011; Wang et al., 2012; Suzuki et al., 2013; Rosenfeld et al., 2019), which is consistent with the suppression of precipitation. Particularly in shallow precipitating BLs $\left(H_{\mathrm{BL}}<1 \mathrm{~km}\right)$, the estimated susceptibility can become very large $\left(s_{\text {lwp }}>0.4\right.$, Fig. 6$)$. Such adjustments would correspond to a considerable enhancement of the negative cloudradiative forcing. However, these shallow, precipitating BLs are rare $(10 \%-25 \%$ of all cloud scenes analysed within the 10-year climatology). Therefore, such cloud scenes are unlikely to govern the radiative forcing of aerosol-cloud interactions.

The LWP adjustment inferred from the entire climatology of marine subtropical stratocumulus $\left(s_{\mathrm{lwp}}=-0.33\right)$ is driven by non-precipitating cloud climatologies which govern the climatological statistics, but are only representative of a small subset of stratocumulus regions in the subtropics. Susceptibility estimates restricted to the phase space of intermittently precipitating climatologies (Fig. 2d), which represent most stratocumulus regions in the subtropics, are lower $\left(s_{\text {lwp }}=-0.23\right)$. Performing a bivariate fit of the $\ln$ LWP phase space, which removes any potential impact of the LWP $-H_{\mathrm{BL}}$ covariance on estimates of $s_{\text {lwp }}$, does not provide substantially different results (Table 1) to previous global es- 
timates of $s_{\text {lwp }}$ in marine low clouds (Michibata et al., 2016; Gryspeerdt et al., 2019).

A further division of the entire phase space into BL-depth regimes showed that, overall, cloud adjustments seem less effective in shallow BLs. The potential increase in LWP adjustment with BL depth has very recently been noted in pollution tracks (Toll et al., 2019). Here, we show that this behaviour may generalise to the whole climatology. The simulated change in $s_{\text {lwp }}$ with $H_{\mathrm{BL}}$ within clouds of intermittent precipitation is consistent with the lower end of $s_{\text {lwp }}$ estimates within the $1 \sigma$ range inferred from pollution tracks. Stratifying the $\ln L W P-\ln N_{\mathrm{d}}$ surface by BL depth further closes the gap between $s_{\text {lwp }}$ estimates inferred from climatology and cloud-scale modelling. Shallow BLs, such as the ones sampled during ASTEX and DYCOMS-II (Fig. 1), are associated with the range $-0.22<s_{\text {lwp }}<-0.1$ (Fig. 6c-d). This is consistent with estimates of $s_{\text {lwp }}$ obtained in LES experiments of these campaigns (Ackerman et al., 2004; Bretherton et al., 2007).

Different remote-sensing-based estimates for $s_{\text {lwp }}$ have been proposed. Their spatial distributions not only differ in magnitude but also in sign among one another (e.g. Michibata et al., 2016, and Gryspeerdt et al., 2019), as well as compared to Fig. 5 of this study. This is likely a result of different methodologies of categorising and processing different retrievals. Different methodologies to distinguish between precipitating and non-precipitating clouds, as well as different methods to retrieve and process $N_{\mathrm{d}}$, may impact $s_{\text {lwp }}$ estimates. In particular, $N_{\mathrm{d}}$ remains a highly uncertain retrieval from space-borne observations. For this study, we chose to limit the uncertainty of the physical retrieval of $N_{\mathrm{d}}$ while capturing as much of the variability in the subtropics as possible. Stricter filtering approaches may yield less retrieval uncertainty, but they may imply a loss of some of the variability characteristic to the system. Either approach could influence $s_{\text {lwp }}$ estimates. Thus our results, like previous studies, are subject to this uncertainty and remain to be verified by independent data sets.

In summary, our results show that aerosol-cloud interactions may manifest differently in deep precipitating, and nonprecipitating, marine BLs as compared to shallow BLs. Furthermore, this work highlights the importance of understanding aerosol-cloud interactions in deep marine stratocumulus, which are underrepresented in currently analysed field data, numerical process models, and pollution tracks.

Data availability. MODIS cloud retrievals were obtained from https://ladsweb.modaps.eosdis.nasa.gov/archive/allData/ 61/MYD08_D3 (Platnick et al., 2015). MERRA-2 data were downloaded from https://disc.gsfc.nasa.gov/datasets (Global Modeling and Assimilation Office, 2015). Albedo fields from CERES were downloaded from https://ceres.larc.nasa.gov/compare_products.php (Doelling, 2016).
Supplement. The supplement related to this article is available online at: https://doi.org/10.5194/acp-20-3609-2020-supplement.

Author contributions. AP conceived this study and wrote the article. RE compiled the remote-sensing retrievals for the study. AP and RE performed the analyses with input from FB and FG. All authors contributed to the discussion of the results and editing of the article.

Competing interests. The authors declare that they have no conflict of interest.

Acknowledgements. We would like to thank Daniel McCoy for initial discussions of the project idea in the context of remote-sensing products, Lukas Josipovic for his technical support in figure optimisation, and Fabian Hoffmann for mixed-layer theory discussions. We also thank the anonymous reviewers for their constructive criticisms, which greatly improved the quality of this article.

Financial support. This research has been supported by the Federal Ministry of Education and Research (BMBF) "Make our Planet Great Again - German Research Initiative" (grant no. 57429624) implemented by the German Academic Exchange Service (DAAD), NASA (grant no. NNXBAQ35G), The Branco Weiss Fellowship - Society in Science, the Dutch Research Council (NWO) (Veni grant), and the Swedish Research Council (grant no. 2018-04274).

Review statement. This paper was edited by Johannes Quaas and reviewed by two anonymous referees.

\section{References}

Ackerman, A. S., Toon, O. B., Taylor, J. P., Johnson, D. W., Hobbs, P. V., and Ferek, R. J.: Effects of Aerosols on Cloud Albedo: Evaluation of Twomey's Parameterization of Cloud Susceptibility Using Measurements of Ship Tracks, J. Atmos. Sci., 57, 2684-2695, https://doi.org/10.1175/15200469(2000)057<2684:EOAOCA>2.0.CO;2, 2000.

Ackerman, A. S., Kirkpatrick, M. P., Stevens, D. E., and Toon, O. B.: The impact of humidity above stratiform clouds on indirect aerosol climate forcing, Nature, 432, 1014-1017, 2004.

Ackerman, A. S., vanZanten, M. C., Stevens, B., SavicJovcic, V., Bretherton, C. S., Chlond, A., Golaz, J.-C., Jiang, H., Khairoutdinov, M., Krueger, S. K., Lewellen, D. C., Lock, A., Moeng, C.-H., Nakamura, K., Petters, M. D., Snider, J. R., Weinbrecht, S., and Zulauf, M.: LargeEddy Simulations of a Drizzling, Stratocumulus-Topped Marine Boundary Layer, Mon. Weather Rev., 137, 1083-1110, https://doi.org/10.1175/2008MWR2582.1, 2009.

Albrecht, B. A.: Aerosols, cloud microphysics, and fractional cloudiness, Science, 245, 1227-1230, 1989. 
Albrecht, B. A., Randall, D. A., and Nicholls, S.: Observations of marine stratocumulus clouds during FIRE, B. Am. Meteorol. Soc., 69, 618-626, 1988.

Albrecht, B. A., Bretherton, C. S., Johnson, D., Schubert, W. S., and Frisch, A. S.: The Atlantic Stratocumulus Transition Experiment - ASTEX, B. Am. Meteorol. Soc., 76, 889-904, 1995.

Andersen, H., Cermak, J., Fuchs, J., Knutti, R., and Lohmann, U.: Understanding the drivers of marine liquid-water cloud occurrence and properties with global observations using neural networks, Atmos. Chem. Phys., 17, 9535-9546, https://doi.org/10.5194/acp-17-9535-2017, 2017.

Augstein, E., Riehl, H., Ostapoff, F., and Wagner, V.: Mass and Energy Transports in an Undisturbed Atlantic Trade-Wind Flow, Mon. Weather Rev., 101, 101-111, https://doi.org/10.1175/15200493(1973)101<0101:MAETIA>2.3.CO;2, 1973.

Bellouin, N., Quaas, J., Morcrette, J.-J., and Boucher, O.: Estimates of aerosol radiative forcing from the MACC re-analysis, Atmos. Chem. Phys., 13, 2045-2062, https://doi.org/10.5194/acp13-2045-2013, 2013.

Bellouin, N., Quaas, J., Gryspeerdt, E., Kinne, S., Stier, P., WatsonParris, D., Boucher, O., Carslaw, K., Christensen, M., Daniau, A.-L., Dufresne, J.-L., Feingold, G., Fiedler, S., Forster, P., Gettelman, A., Haywood, J., Lohmann, U., Malavelle, F., Mauritsen, T., McCoy, D., Myhre, G., Mülmenstädt, J., Neubauer, D., Possner, A., Rugenstein, M., Sato, Y., Schulz, M., Schwartz, S., Sourdeval, O., Storelvmo, T., Toll, V., Winker, D., and Stevens, B.: Bounding global aerosol radiative forcing of climate change, Rev. Geophys., https://doi.org/10.1029/2019RG000660, online first, 2019.

Bender, F. A.-M., Charlson, R. J., Ekman, A. M. L., and Leahy, L. V.: Quantification of Monthly Mean Regional-Scale Albedo of Marine Stratiform Clouds in Satellite Observations and GCMs, J. Appl. Meteorol. Clim., 50, 2139-2148, https://doi.org/10.1175/JAMC-D-11-049.1, 2011.

Bender, F. A.-M., Engström, A., and Karlsson, J.: Factors Controlling Cloud Albedo in Marine Subtropical Stratocumulus Regions in Climate Models and Satellite Observations, J. Climate, 29, 3559-3587, https://doi.org/10.1175/JCLI-D-15-0095.1, 2016.

Bender, F. A.-M., Frey, L., McCoy, D. T., Grosvenor, D. P., and Mohrmann, J. K.: Assessment of aerosol-cloud-radiation correlations in satellite observations, climate models and reanalysis, Clim. Dynam., 52, 4371-4392, https://doi.org/10.1007/s00382018-4384-z, 2019.

Bennartz, R.: Global assessment of marine boundary layer cloud droplet number concentration from satellite, J. Geophys. Res.Atmos., 112, D02201, https://doi.org/10.1029/2006JD007547, 2007.

Berner, A. H., Bretherton, C. S., Wood, R., and Muhlbauer, A.: Marine boundary layer cloud regimes and POC formation in a CRM coupled to a bulk aerosol scheme, Atmos. Chem. Phys., 13, 12549-12572, https://doi.org/10.5194/acp-13-125492013, 2013.

Boers, R., Acarreta, J. R., and Gras, J. L.: Satellite monitoring of the first indirect aerosol effect: Retrieval of the droplet concentration of water clouds, J. Geophys. Res.-Atmos., 111, D22208, https://doi.org/10.1029/2005JD006838, 2006.

Boucher, O., Randall, D., Artaxo, P., Bretherton, C., Feingold, G., Forster, P., Kerminen, V.-M., Kondo, Y., Liao, H., Lohmann, U., Rasch, P., Satheesh, S. K., Sherwood, S., Stevens, B., and Zhang,
X. Y.: Clouds and Aerosols, in: Climate Change 2013: The physical science basis. Contribution of Working Group I to the Fifth Assessment Report of the Intergovernmental Panel on Climate Change, Cambridge University Press, edited by: Stocker, T., Qin, D., Plattner, G.-K., Tignor, M., Allen, S., Boschung, J., Nauels, A., Xia, Y., Bex, V., and Midgley, P. M., Cambridge University Press, Cambridge, UK and New York, NY, USA, 2013.

Braun, R. A., Dadashazar, H., MacDonald, A. B., Crosbie, E., Jonsson, H. H., Woods, R. K., Flagan, R. C., Seinfeld, J. H., and Sorooshian, A.: Cloud Adiabaticity and Its Relationship to Marine Stratocumulus Characteristics Over the Northeast Pacific Ocean, J. Geophys. Res.-Atmos., 123, 13790-13806, https://doi.org/10.1029/2018JD029287, 2018.

Bretherton, C. S., Uttal, T., Fairall, C. W., Yuter, S. E., Weller, R. A., Baumgardner, D., Comstock, K., Wood, R., and Raga, G. B.: The EPIC 2001 stratodumulus study, Am. Meteorol. Soc., 85, 967977, 2004.

Bretherton, C. S., Blossey, P. N., and Uchida, J.: Cloud droplet sedimentation, entrainment efficiency, and subtropical stratocumulus albedo, Geophys. Res. Lett., 34, L03813, https://doi.org/10.1029/2006GL027648, 2007.

Bretherton, C. S., Blossey, P. N., and Jones, C. R.: Mechanisms of marine low cloud sensitivity to idealized climate perturbations: A single-LES exploration extending the CGILS cases, J. Adv. Model. Earth Sy., 5, 316-337, https://doi.org/10.1002/jame.20019, 2013.

Caldwell, P. and Bretherton, C. S.: Response of a Subtropical Stratocumulus-Capped Mixed Layer to Climate and Aerosol Changes, J. Climate, 22, 20-38, https://doi.org/10.1175/2008JCLI1967.1, 2009.

Campmany, E., Grainger, R. G., Dean, S. M., and Sayer, A. M.: Automatic detection of ship tracks in ATSR-2 satellite imagery, Atmos. Chem. Phys., 9, 1899-1905, https://doi.org/10.5194/acp9-1899-2009, 2009.

Charlson, R. J., Ackerman, A. S., Bender, F. A.-M., Anderson, T. L., and Liu, Z.: On the climate forcing consequences of the albedo continuum between cloudy and clear air, Tellus B, 59, 715-727, https://doi.org/10.1111/j.1600-0889.2007.00297.x, 2007.

Chen, G., Wang, W.-C., and Chen, J.-P.: Aerosol-stratocumulusradiation interactions over the southeast Pacific, J. Atmos. Sci., 72, 2612-2621, 2015.

Christensen, M. W. and Stephens, G. L.: Microphysical and macrophysical responses of marine stratocumulus polluted by underlying ships: Evidence of cloud deepening, J. Geophys. Res.Atmos., 116, D03201, https://doi.org/10.1029/2010JD014638, 2011.

Christensen, M. W., Suzuki, K., Zambri, B., and Stephens, G. L.: Ship track observations of a reduced shortwave aerosol indirect effect in mixed-phase clouds, Geophys. Res. Lett., 41, 69706977, https://doi.org/10.1002/2014GL061320, 2014.

Dal Gesso, S., Siebesma, A. P., de Roode, S. R., and van Wessem, J. M.: A mixed-layer model perspective on stratocumulus steady states in a perturbed climate, Q. J. Roy. Meteor. Soc., 140, 21192131, https://doi.org/10.1002/qj.2282, 2014.

Doelling, D.: CERES Level 3 SSF1deg-Day AquaMODIS HDF file - Edition 4A [Data set], https://doi.org/10.5067/AQUA/CERES/SSF1DEGDAY_L3.004A, 2016. 
Durkee, P. A., Noone, K. J., and Bluth, R. T.: The Monterey Area Ship Track Experiment, J. Atmos. Sci., 57, 2523-2541, 2000.

Eastman, R. and Wood, R.: Factors Controlling Low-Cloud Evolution over the Eastern Subtropical Oceans: A Lagrangian Perspective Using the A-Train Satellites, J. Atmos. Sci., 73, 331-351, https://doi.org/10.1175/JAS-D-15-0193.1, 2016.

Eastman, R. and Wood, R.: The Competing Effects of Stability and Humidity on Subtropical Stratocumulus Entrainment and Cloud Evolution from a Lagrangian Perspective, J. Atmos. Sci., 75, 2563-2578, https://doi.org/10.1175/JAS-D-18-0030.1, 2018.

Eastman, R., Wood, R., and Ting O, K.: The Subtropical Stratocumulus-Topped Planetary Boundary Layer: A Climatology and the Lagrangian Evolution, J. Atmos. Sci., 74, 2633 2656, https://doi.org/10.1175/JAS-D-16-0336.1, 2017.

Eastman, R., Lebsock, M., and Wood, R.: Warm Rain Rates from AMSR-E 89-GHz Brightness Temperatures Trained Using CloudSat Rain-Rate Observations, J. Atmos. Ocean. Tech., 36, 1033-1051, https://doi.org/10.1175/JTECH-D-18-0185.1, 2019.

Ghonima, M. S., Norris, J. R., Heus, T., and Kleissl, J.: Reconciling and Validating the Cloud Thickness and Liquid Water Path Tendencies Proposed by R. Wood and J. J. van der Dussen et al., J. Atmos. Sci., 72, 2033-2040, https://doi.org/10.1175/JAS-D-140287.1, 2015.

Glassmeier, F., Hoffmann, F., Johnson, J. S., Yamaguchi, T., Carslaw, K. S., and Feingold, G.: An emulator approach to stratocumulus susceptibility, Atmos. Chem. Phys., 19, 1019110203, https://doi.org/10.5194/acp-19-10191-2019, 2019.

Global Modeling and Assimilation Office (GMAO): MERRA-2 inst3_3d_asm_Nv: 3d, 3-Hourly, Instantaneous, ModelLevel, Assimilation, Assimilated Meteorological Fields V5.12.4, Greenbelt, MD, USA, Goddard Earth Sciences Data and Information Services Center (GES DISC), https://doi.org/10.5067/WWQSXQ8IVFW8, 2015.

Goren, T., Rosenfeld, D., Sourdeval, O., and Quaas, J.: Satellite Observations of Precipitating Marine Stratocumulus Show Greater Cloud Fraction for Decoupled Clouds in Comparison to Coupled Clouds, Geophys. Res. Lett., 45, 5126-5134, https://doi.org/10.1029/2018GL078122, 2018.

Grosvenor, D. P. and Wood, R.: The effect of solar zenith angle on MODIS cloud optical and microphysical retrievals within marine liquid water clouds, Atmos. Chem. Phys., 14, 7291-7321, https://doi.org/10.5194/acp-14-7291-2014, 2014.

Gryspeerdt, E., Quaas, J., and Bellouin, N.: Constraining the aerosol influence on cloud fraction, J. Geophys. Res.-Atmos., 121, 35663583, https://doi.org/10.1002/2015JD023744, 2016.

Gryspeerdt, E., Quaas, J., Ferrachat, S., Gettelman, A., Ghan, S., Lohmann, U., Morrison, H., Neubauer, D., Partridge, D. G., Stier, P., Takemura, T., Wang, H., Wang, M., and Zhang, K.: Constraining the instantaneous aerosol influence on cloud albedo, P. Natl. Acad. Sci. USA, 114, 4899-4904, https://doi.org/10.1073/pnas.1617765114, 2017.

Gryspeerdt, E., Goren, T., Sourdeval, O., Quaas, J., Mülmenstädt, J., Dipu, S., Unglaub, C., Gettelman, A., and Christensen, M.: Constraining the aerosol influence on cloud liquid water path, Atmos. Chem. Phys., 19, 5331-5347, https://doi.org/10.5194/acp19-5331-2019, 2019.

Hahn, C. J. and Warren, S. G.: A Gridded Climatology of Clouds over Land (1971-1996) and Ocean (1954-2008) from Surface Observations Worldwide (NDP-026E)*, Environmental System
Science Data Infrastructure for a Virtual Ecosystem; Carbon Dioxide Information Analysis Center (CDIAC), Oak Ridge National Laboratory (ORNL), Oak Ridge, TN (United States), https://doi.org/10.3334/CDIAC/cli.ndp026e, 2007.

Hill, A. A. and Dobbie, S.: The impact of aerosols on non-precipitating marine stratocumulus. II: The semidirect effect, Q. J. Roy. Meteor. Soc., 134, 1155-1165, https://doi.org/10.1002/qj.277, 2008.

Hill, A. A. and Feingold, G.: The influence of entrainment and mixing assumption on aerosol-cloud interactions in marine stratocumulus, J. Atmos. Sci., 66, 1450-1464, https://doi.org/10.1175/2008JAS2909.1, 2009.

Hill, A. A., Dobbie, S., and Yin, Y.: The impact of aerosols on nonprecipitating marine stratocumulus. I: Model description and prediction of the indirect effect, Q. J. Roy. Meteor. Soc., 134, 11431154, https://doi.org/10.1002/qj.278, 2008.

Hoffmann, F., Glassmeier, F., Yamaguchi, T., and Feingold, G.: Liquid Water Path Steady States in Stratocumulus: Insights From Process-Level Emulation and Mixed-Layer Theory, J. Atmos. Sci., in review, 2020.

Jenkins, A. K. L., Forster, P. M., and Jackson, L. S.: The effects of timing and rate of marine cloud brightening aerosol injection on albedo changes during the diurnal cycle of marine stratocumulus clouds, Atmos. Chem. Phys., 13, 1659-1673, https://doi.org/10.5194/acp-13-1659-2013, 2013.

Jiang, H., Feingold, G., and Cotton, W. R.: Simulations of aerosolcloud-dynamical feedbacks resulting from entrainment of aerosol into the marine boundary layer during the Atlantic Stratocumulus Transition Experiment, J. Geophys. Res.-Atmos., 107, AAC20-1-AAC20-11, https://doi.org/10.1029/2001JD001502, 2002.

Jiang, H., Xue, H., Teller, A., Feingold, G., and Levin, Z.: Aerosol effects on the lifetime of shallow cumulus, Geophys. Res. Lett. 33, L14806, https://doi.org/10.1029/2006GL026024, 2006.

Johnson, B. T., Shine, K. P., and Forster, P. M.: The semidirect aerosol effect: Impact of absorbing aerosols on marine stratocumulus, Q. J. Roy. Meteor. Soc., 130, 1407-1422, https://doi.org/10.1256/qj.03.61, 2004.

Kato, S., Loeb, N. G., Rose, F. G., Doelling, D. R., Rutan, D. A., Caldwell, T. E., Yu, L., and Weller, R. A.: Surface Irradiances Consistent with CERES-Derived Top-of-Atmosphere Shortwave and Longwave Irradiances, J. Climate, 26, 27192740, https://doi.org/10.1175/JCLI-D-12-00436.1, 2013.

King, M. D., Menzel, W. P., Kaufman, Y. J., Tanre, D., , Platnick, S., Ackerman, S. A., Remer, L. A., Pincus, R., and Hubanks, P. A.: Cloud and aerosol properties, precipitable water, and profiles of temperature and water vapor from MODIS, IEEE T. Geosci. Remote Sens., 41, 442-458, https://doi.org/10.1109/TGRS.2002.808226, 2003.

Lebsock, M. D., Stephens, G. L., and Kummerow, C.: Multisensor satellite observations of aerosol effects on warm clouds, J. Geophys. Res.-Atmos., 113, D15205, https://doi.org/10.1029/2008JD009876, 2008.

Lenschow, D. H., Paluch, I. R., Bandy, A. R., Pearson, R., Kawa, S. R., Weaver, C. J., Huebert, B. J., Kay, J. G., Thornton, D. C., and III, A. R. D.: Dynamics and Chemistry of Marine Stratocumulus (DYCOMS) Experiment, B. Am. Meteorol. Soc., 69, 1058-1067, 1988. 
Lu, M. L. and Seinfeld, J. H.: Study of the aerosol indirect effect by large-eddy simulation of marine stratocumulus, J. Atmos. Sci., 62, 3909-3932, 2005.

Lu, M. L., Conant, W. C., Jonsson, H. H., Varutbangkul, V., Flagan, R. C., and Seinfeld, J. H.: The Marine Stratus/Stratocumulus Experiment (MASE): Aerosol-cloud relationships in marine stratocumulus, J. Geophys. Res., 112, D10209, https://doi.org/10.1029/2006JD007985, 2007.

Lu, M.-L., Sorooshian, A., Jonsson, H. H., Feingold, G., Flagan, R. C., and Seinfeld, J. H.: Marine stratocumulus aerosol-cloud relationships in the MASE-II experiment: Precipitation susceptibility in eastern Pacific marine stratocumulus, J. Geophys. Res.Atmos., 114, D24203, https://doi.org/10.1029/2009JD012774, 2009.

Malavelle, F. F., Haywood, J. M., Jones, A., Gettelman, A., Clarisse, L., Bauduin, S., Allan, R. P., Karset, I. H. H., Kristjánsson, J. E., Oreopoulos, L., Cho, N., Lee, D., Bellouin, N., Boucher, O., Grosvenor, D. P., Carslaw, K. S., Dhomse, S., Mann, G. W., Schmidt, A., Coe, H., Hartley, M. E., Dalvi, M., Hill, A. A., Johnson, B. T., Johnson, C. E., Knight, J. R., O'Connor, F. M., Partridge, D. G., Stier, P., Myhre, G., Platnick, S., Stephens, G. L., Takahashi, H., and Thordarson, T.: Erratum: Strong constraints on aerosol-cloud interactions from volcanic eruptions, Nature, 546, 485-491, https://doi.org/10.1038/nature24275, 2017.

McComiskey, A. and Feingold, G.: The scale problem in quantifying aerosol indirect effects, Atmos. Chem. Phys., 12, 1031-1049, https://doi.org/10.5194/acp-12-1031-2012, 2012.

McCoy, D. T., Bender, F. A.-M., Mohrmann, J. K. C., Hartmann, D. L., Wood, R., and Grosvenor, D. P.: The global aerosolcloud first indirect effect estimated using MODIS, MERRA, and AeroCom, J. Geophys. Res.-Atmos., 122, 1779-1796, https://doi.org/10.1002/2016JD026141, 2017.

Mechem, D. B., Yuter, S. E., and de Szoeke, S. P.: Thermodynamic and Aerosol Controls in Southeast Pacific Stratocumulus, J. Atmos. Sci., 69, 1250-1266, https://doi.org/10.1175/JAS-D11-0165.1, 2012.

Merk, D., Deneke, H., Pospichal, B., and Seifert, P.: Investigation of the adiabatic assumption for estimating cloud micro- and macrophysical properties from satellite and ground observations, Atmos. Chem. Phys., 16, 933-952, https://doi.org/10.5194/acp-16933-2016, 2016.

Michibata, T., Suzuki, K., Sato, Y., and Takemura, T.: The source of discrepancies in aerosol-cloud-precipitation interactions between GCM and A-Train retrievals, Atmos. Chem. Phys., 16, 15413-15424, https://doi.org/10.5194/acp-16-154132016, 2016.

Molod, A., Takacs, L., Suarez, M., and Bacmeister, J.: Development of the GEOS-5 atmospheric general circulation model: evolution from MERRA to MERRA2, Geosci. Model Dev., 8, 1339-1356, https://doi.org/10.5194/gmd-8-1339-2015, 2015.

Muhlbauer, A., McCoy, I. L., and Wood, R.: Climatology of stratocumulus cloud morphologies: microphysical properties and radiative effects, Atmos. Chem. Phys., 14, 6695-6716, https://doi.org/10.5194/acp-14-6695-2014, 2014.

Petters, J. L., Jiang, H., Feingold, G., Rossiter, D. L., Khelif, D., Sloan, L. C., and Chuang, P. Y.: A comparative study of the response of modeled non-drizzling stratocumulus to meteorological and aerosol perturbations, Atmos. Chem. Phys., 13, 25072529, https://doi.org/10.5194/acp-13-2507-2013, 2013.
Platnick, S., King, M. D., Ackermann, S. A., Menzel, W. P., Baum, B. A., Riedi, J. C., and Frey, R. A.: The MODIS cloud products: Algorithms and examples from TERRA, IEEE T. Geosci. Remote Sens., 41, 459-473, https://doi.org/10.1109/TGRS.2002.808301, 2003.

Platnick, S., Hubanks, P., Meyer, K., and King, M. D.: MODIS Atmosphere L3 Monthly Product (08_L3), Collection 6.1. NASA Level-3 and Atmosphere Archive \& Distribution System (LAADS) Distributed Active Archive Center (DAAC), Goddard Space Flight Center, Greenbelt, available at: https://ladsweb.modaps.eosdis.nasa.gov/archive/allData/ 61/MYD08_D3 (last access: 30 January 2019), 2015.

Platnick, S., Meyer, K. G., King, M. D., Wind, G., Amarasinghe, N., Marchant, B., Arnold, G. T., Zhang, Z., Hubanks, P. A., Holz, R. E., Yang, P., Ridgway, W. L., and Riedi, J.: The MODIS Cloud Optical and Microphysical Products: Collection 6 Updates and Examples From Terra and Aqua, IEEE T. Geosci. Remote Sens., 55, 502-525, https://doi.org/10.1109/TGRS.2016.2610522, 2017.

Possner, A., Wang, H., Wood, R., Caldeira, K., and Ackerman, T. P.: The efficacy of aerosol-cloud radiative perturbations from nearsurface emissions in deep open-cell stratocumuli, Atmos. Chem. Phys., 18, 17475-17488, https://doi.org/10.5194/acp-18-174752018, 2018.

Quaas, J., Boucher, O., Bellouin, N., and Kinne, S.: Satellitebased estimate of the direct and indirect aerosol climate forcing, J. Geophys. Res.-Atmos., 113, D05204, https://doi.org/10.1029/2007JD008962, 2008.

Rienecker, M. M., Suarez, M. J., Gelaro, R., Todling, R., Bacmeister, J., Liu, E., Bosilovich, M. G., Schubert, S. D., Takacs, L., Kim, G.-K., Bloom, S., Chen, J., Collins, D., Conaty, A., da Silva, A., Gu, W., Joiner, J., Koster, R. D., Lucchesi, R., Molod, A., Owens, T., Pawson, S., Pegion, P., Redder, C. R., Reichle, R., Robertson, F. R., Ruddick, A. G., Sienkiewicz, M., and Woollen, J.: MERRA: NASA's Modern-Era Retrospective Analysis for Research and Applications, J. Climate, 24, 3624-3648, https://doi.org/10.1175/JCLI-D-11-00015.1, 2011.

Rosenfeld, D., Zhu, Y., Wang, M., Zheng, Y., Goren, T., and Yu, S.: Aerosol-driven droplet concentrations dominate coverage and water of oceanic low-level clouds, Science, 363, eaav0566, https://doi.org/10.1126/science.aav0566, 2019.

Sandu, I., Brenguier, J.-L., Geoffroy, O., Thouron, O., and Masson, V.: Aerosol Impacts on the Diurnal Cycle of Marine Stratocumulus, J. Atmos. Sci., 65, 2705-2718, https://doi.org/10.1175/2008JAS2451.1, 2008.

Sandu, I., Brenguier, J.-L., Thouron, O., and Stevens, B.: How important is the vertical structure for the representation of aerosol impacts on the diurnal cycle of marine stratocumulus?, Atmos. Chem. Phys., 9, 4039-4052, https://doi.org/10.5194/acp-9-40392009, 2009.

Seifert, A., Heus, T., Pincus, R., and Stevens, B.: Large-eddy simulation of the transient and near-equilibrium behavior of precipitating shallow convection, J. Adva. Model. Earth Sy., 7, 19181937, https://doi.org/10.1002/2015MS000489, 2015.

Sekiguchi, M., Nakajima, T., Suzuki, K., Kawamoto, K., Higurashi, A., Rosenfeld, D., Sano, I., and Mukai, S.: A study of the direct and indirect effects of aerosols using global satellite data sets of aerosol and cloud parameters, J. Geophys. Res.-Atmos., 108, 4699, https://doi.org/10.1029/2002JD003359, 2003. 
Smith, S. J. and Bond, T. C.: Two hundred fifty years of aerosols and climate: the end of the age of aerosols, Atmos. Chem. Phys., 14, 537-549, https://doi.org/10.5194/acp-14-537-2014, 2014.

Stevens, B., Lenschow, D. H., Vali, G., Gerber, H., Bandy, A., Blomquist, B., Brenguier, J.-L., Bretherton, C. S., Burnet, F., Campos, T., Chai, S., Faloona, I., Haimov, D. F. S., Laursen, K., Lilly, D. K., Loehrer, S. M., Malinowski, S. P., Morley, B., Petters, M. D., Rogers, D. C., Russel, L., Savic-Jovcic, V., Snider, J. R., Straub, D., Szumowski, M. J., Takagi, H., Thornton, D. C., Tschudi, M., Twohy, C., Wetzel, M., and van Zanten, M. C.: Dynamics and chemistry of marine stratocumulus - DYCOMS-II, Am. Meteorol. Soc., 84, 579-593, 2003.

Suzuki, K., Stephens, G. L., and Lebsock, M. D.: Aerosol effect on the warm rain formation process: Satellite observations and modeling, J. Geophys. Res.-Atmos., 118, 170-184, https://doi.org/10.1002/jgrd.50043, 2013.

Toll, V., Christensen, M., Gassó, S., and Bellouin, N.: Volcano and ship tracks indicate excessive aerosol-induced cloud water increases in a climate model, Geophys. Res. Lett., 44, 12492 12500, https://doi.org/10.1002/2017GL075280, 2017.

Toll, V., Christensen, M., Quaas, J., and Bellouin, N.: Weak average liquid-cloud-water response to anthropogenic aerosols, Nature, 572, 51-55, https://doi.org/10.1038/s41586-019-1423-9, 2019.

Tonttila, J., Maalick, Z., Raatikainen, T., Kokkola, H., Kühn, T., and Romakkaniemi, S.: UCLALES-SALSA v1.0: a largeeddy model with interactive sectional microphysics for aerosol, clouds and precipitation, Geosci. Model Dev., 10, 169-188, https://doi.org/10.5194/gmd-10-169-2017, 2017.

Twohy, C. H., Coakley Jr., J. A., and Tahnk, W. R.: Effect of changes in relative humidity on aerosol scattering near clouds, J. Geophys. Res.-Atmos., 114, D05205, https://doi.org/10.1029/2008JD010991, 2009.

Twomey, S.: Aerosols, clouds and radiation, Atmos. Environ., 25, 2435-2442, 1991.

van der Dussen, J. J., de Roode, S. R., and Siebesma, A. P.: Factors Controlling Rapid Stratocumulus Cloud Thinning, J. Atmos. Sci., 71, 655-664, https://doi.org/10.1175/JAS-D-130114.1, 2014.

Vaughan, M., Young, S., Winker, D., Powell, K., Omar, A., Liu, $\mathrm{Z}$., $\mathrm{Hu}, \mathrm{Y}$., and Hostetler, C.: Fully automated analysis of spacebased lidar data: an overview of the CALIPSO retrieval algorithms and data products, SPIE Int. Soc. Opt. Eng., 5575, 16-30, https://doi.org/10.1117/12.572024, 2004.
Wang, M., Ghan, S., Liu, X., L'Ecuyer, T. S., Zhang, K., Morrison, H., Ovchinnikov, M., Easter, R., Marchand, R., Chand, D., Quian, Y., and Penner, J. E.: Constraining cloud lifetime effects of aerosols using A-Train satellite observations, Geophys. Res. Lett., 39, L15709, https://doi.org/10.1029/2012GL052204, 2012.

Wood, R.: Cancellation of aerosol indirect effects in marine stratocumulus through Cloud thinning, Am. Meteorol. Soc., 7, 2657 2669, https://doi.org/10.1175/JAS3942.1, 2007.

Wood, R.: Review: Stratocumulus Clouds, Mon. Weather Rev., 140, 2373-2423, 2012.

Wood, R., Bretherton, C. S., Leon, D., Clarke, A. D., Zuidema, P., Allen, G., and Coe, H.: An aircraft case study of the spatial transition from closed to open mesoscale cellular convection over the Southeast Pacific, Atmos. Chem. Phys., 11, 234-2370, https://doi.org/10.5194/acp-11-2341-2011, 2011.

Xue, H., Feingold, G., and Stevens, B.: Aerosol Effects on Clouds, Precipitation, and the Organization of Shallow Cumulus Convection, J. Atmos. Sci., 65, 392-406, https://doi.org/10.1175/2007JAS2428.1, 2008.

Yi, L., Kogan, Y. L., and Mechem, D. B.: An idealized modeling study of the effect of continental air mass aerosol parameters on marine stratocumulus, Atmos. Res., 88, 157-167, https://doi.org/10.1016/j.atmosres.2007.10.010, 2008.

Yuan, T., Wang, C., Song, H., Platnick, S., Meyer, K., and Oreopoulos, L.: Automatically Finding Ship Tracks to Enable LargeScale Analysis of Aerosol-Cloud Interactions, Geophys. Res. Lett., 46, 7726-7733, https://doi.org/10.1029/2019GL083441, 2019.

Zelinka, M. D., Andrews, T., Forster, P. M., and Taylor, K. E.: Quantifying components of aerosol-cloud-radiation interactions in climate models, J. Geophys. Res.-Atmos., 119, 7599-7615, https://doi.org/10.1002/2014JD021710, 2014.

Zhou, X., Heus, T., and Kollias, P.: Influences of drizzle on stratocumulus cloudiness and organization, J. Geophys. Res.-Atmos., 122, 6989-7003, https://doi.org/10.1002/2017JD026641, 2017.

Zuidema, P., Redemann, J., Haywood, J., Wood, R., Piketh, S., Hipondoka, M., and Formenti, P.: Smoke and Clouds above the Southeast Atlantic: Upcoming Field Campaigns Probe Absorbing Aerosol's Impact on Climate, B. Am. Meteorol. Soc., 97, 1131-1135, https://doi.org/10.1175/BAMS-D-15-00082.1, 2016. 